\title{
Research Paper Market dynamics and export of major solanaceous vegetables in India
}

See end of the paper for authors' affiliations

Correspondence to :

NIRMAL DE

Department of Soil Science and Agricultural Chemistry, Institute of Agricultural Sciences, Banaras Hindu University, VARANASI (U.P.) INDIA Email:nirmalde@gmail.com

Paper History :

Received : 28.01.2014.

Revised : 25.01.2015;

Accepted : 11.02.2015
ABSTRACT : The cumulative growth rate of vegetable productivity in India is more than changes in world productivity of 15.1 per cent during 1992-2008. The country has witnessed a cumulative growth of 31.8 per cent of onion production, 22.8 per cent growth of tomato and $(-11.3 \%)$ in potato crop during last decade. India contributes about 13 per cent of the total world production of vegetables. Of the total vegetable production in India, potato accounts for 27.6 per cent, onion 10.6 per cent and tomato 8.9 per cent share. The impressive growth rate of vegetable export from India at 9.8 per cent per annum is recorded in last decade. The analysis of quantum share of exports to total production was found to be very low, particularly in potato and tomato crops when compared against onion crop. In global market export of onion stands tall as compared trade share for potato and tomato is negligible. While, in domestic market trade share and consumers preference follows potato, onion and tomato sequence. The very low export performance ratio or RCA and negative value of revealed symmetric comparative advantage (RSCA) revealed that both potato and tomato were not export competitive. The high per cent coefficient of variation was used as an index of instability in tomato as well as potato export from India.

KEY WORDS : Vegetables, Trend analysis, Production-productivity, Export index (EPR/ RCA, RSCA, Coefficient of variation)

HOW TO CITE THIS PAPER : De, Chhabi, Dey, Baby and De, Nirmal (2015). Market dynamics and export of major solanaceous vegetables in India. Internat. Res. J. Agric. Eco. \& Stat., 6 (1) : 126-131. 